\title{
Eco Valley or New Vraja Dham? Competing Emic Interpretations of the Hungarian Krishna Valley
}

\author{
Judit Farkas
}

check for updates

Citation: Farkas, Judit. 2021. Eco Valley or New Vraja Dham? Competing Emic Interpretations of the Hungarian Krishna Valley. Religions 12: 622. https://doi.org/ $10.3390 /$ rel12080622

Academic Editors: Knut Axel Jacobsen and Roberto Cipriani

Received: 30 May 2021

Accepted: 5 August 2021

Published: 10 August 2021

Publisher's Note: MDPI stays neutral with regard to jurisdictional claims in published maps and institutional affiliations.

Copyright: (C) 2021 by the author. Licensee MDPI, Basel, Switzerland. This article is an open access article distributed under the terms and conditions of the Creative Commons Attribution (CC BY) license (https:// creativecommons.org/licenses/by/ $4.0 /)$.
Department of European Ethnology and Cultural Anthropology, University of Pécs, 7622 Pécs, Hungary; farkas.judit@pte.hu

\begin{abstract}
One of the reasons for the spread of the Western Hare Krishna movement is that it offers several alternatives for the practice of religion: devotees can be full-fledged members of the church in congregations located in complex urban or in simple rural contexts. An example of the latter is Krishna Valley, where approximately 130 Krishna-devotees live austere lives. My paper presents the interpretations of this settlement concentrating on (multiple) internal (emic) views: On the one hand, I will show how the leadership of the church contextualizes and interprets Krishna Valley and how they wish the inhabitants to conceptualize it. On the other hand, I will also show what Krishna Valley means for its ordinary inhabitants and what interpretations those living there attach to it. When I was gathering material for the current paper, Krishna Valley was in flux. The settlement has always favored following a sustainable lifestyle but-due in part to the strengthening of the Hungarian eco-village movement-it was at this time that the conceptualization of Krishna Valley as an eco-village gained momentum. This was the heyday of the Eco Valley Foundation, which was to strengthen the eco-village aspect of the Valley, and in the communication of Krishna Valley the ecological aspect became paramount, drowning out all other interpretations. Not all inhabitants of the village welcomed this change and in response some began to emphasize the interpretation of Krishna Valley as a sacred place. In the current paper, I will present these two processes and the relationship between them through the lens of the interpretations of the members of the community.
\end{abstract}

Keywords: eco-spirituality; eco-villages; Hare Krishnas

\section{Introduction}

One of the reasons for the spread of the Western Hare Krishna movement is that it offers several alternatives for the practice of religion: devotees can be full-fledged members of the church in congregations located in complex urban or in simple rural contexts. An example of the latter is Krishna Valley, where approximately 130 Krishna-devotees live very modest, self-sufficient lives.

My paper presents the interpretations of this settlement concentrating on (multiple) internal (emic) views: On the one hand, I will show how the leadership of the church contextualizes and interprets Krishna Valley and how they wish the inhabitants to conceptualize it. On the other hand, I will also show what Krishna Valley means for its ordinary inhabitants and what interpretations those living there attach to it.

This paper is part of a longer research: Between 1997 and 2005 I carried out cultural anthropological fieldwork among Hungarian Krishna-devotees for my doctoral dissertation (Farkas 2009). Upon completing my dissertation my attention turned to the study of Hungarian eco-villages, but because Krishna Valley is one of the most significant ecovillages in Hungary, this did not mean that I completely abandoned my original topic. I continued to do fieldwork, now also with a focus on ecology: I studied the community's concept of nature, the eco-conscious elements ${ }^{1}$ in their way of living, and closely followed the formation of the so-called Eco Valley project, the aim of which was to study and strengthen the ecological aspect within the community, while also communicating it to the outside world. 
When I was gathering material for the current paper (2010-2011), Krishna Valley was in flux. The settlement has always favored following a sustainable lifestyle butdue in part to the strengthening of the Hungarian eco-village movement-it was at this time that the conceptualization of Krishna Valley as an eco-village gained momentum. Not all inhabitants of the village welcomed this change, and in response, some began to emphasize the interpretation of Krishna Valley as a sacred place. In the current paper, I will present these two processes and the relationship between them through the lens of the interpretations of the members of the community.

I chose this approach consciously: as a cultural anthropologist I believe in the importance of learning emic interpretations and bringing to light individual voices in a seemingly homogenous community. Therefore, my paper uses individual stories to reveal those interpretative processes that are necessary for a better understanding of the complex meanings of Krishna Valley. ${ }^{2}$

\section{Methods}

As I mentioned above, in my research I have worked with methods commonly used in cultural anthropology. I conducted long-term participatory observation in the community. For this particular study, I conducted 12 interviews ( 10 women, 2 men, from 30 to 70 years old) and also used relevant material from previous interviews on other topics. I talked a lot with the village leader who urged and managed the Eco Valley project. I followed the online activities of the community and processed the relevant written sources. I also made a questionnaire in cooperation with the Eco Valley project. We were primarily interested in how eco-conscious the valley-dwellers were. For the purposes of this paper, the questions "Why did you move to Krishna Valley?" and "What are the three things you most like in Krishna Valley?" proved to be the most useful. At the time, only 34 of the 130 inhabitants answered the questionnaire, thus it could not be called representative. However, my long-term fieldwork with the community indicates that the answers are indeed suitable for assessing trends.

\subsection{Krishna-Devotees, Krishna Valley in Hungary}

The western religious movement and church of Krishna consciousness (International Society for Krishna Consciousness) was created in the United States in the mid-1960s by A.C. Bhaktivedanta Prabhupada, an Indian guru. In terms of faith and lifestyle, the Hare Krishna movement is related to the fifteenth-century reform movement of Hinduism called Gaudiya Vaishnavism. ${ }^{3}$ In Hungary, Krishna-devotees built their first communities in the mid-1970s, which, at the time, was still illegal, and they have existed as an officially recognized church since 1989, as the Hungarian Society for Krishna Consciousness. ${ }^{4}$ Under the influence of the founder, A. C. Bhaktivedanta Prabhupada, one of the important aspirations of the Krishna movement is the creation of religiously based self-sufficient farming communities. ${ }^{5}$ In Hungary, the Krishna devotees arrived to Somogyvámos, a remote village in Somogy County (South Hungary), at the beginning of the 1990s where the local mayor recognized that their settling could hold economic opportunities and accepted the community's request to settle there. In 1993, they then purchased at auction 120 hectares (1.2 square kilometers) of land from the locals ${ }^{6}$ and set out to create the longed-for Krishna village. The groundbreaking ceremony was held in February 1994, and the temple was consecrated on 5 September 1996. Administratively, Krishna Valley (its full name is Krishna Valley Indian Cultural Center and Organic Farm, hence the frequent references to Farm when talking about the community) belongs to the village of Somogyvámos. Since then, the number of Krishna-devotees living in Somogyvámos village (i.e., not in Krishna Valley) and in a nearby village, Somogyvár, has increased significantly (to approximately 150). Currently, there are two Krishna-devotees among the 5-member local government of Somogyvámos village, and one of them is the deputy mayor.

The territory of Krishna Valley is 266 hectares (2.66 square kilometers) and, at present, it has 130 inhabitants (who must be Krishna-devotees). On these 266 hectares, we can find 
the residential area (dwellings with gardens, streets) and the agricultural area and buildings (arable land, pasture, orchards, horticultural gardens), apiary, dairy farm, hothouses, storage areas), parks, forests, botanical garden, various institutions (school, office building, library, reception building), and, at the center, the temple complex (including temple room, cloisters, kitchens, souvenir shop, baby care room, canteen, washroom, offices). The motto of Krishna Valley-taken from the founding Indian guru, Srila Prabhupada is: "simple life and deep thinking" by which they mean religious values and a lifestyle centered on religion. Simple life indeed means a modest lifestyle based on a "bare bones" infrastructure. Krishna Valley is not connected to the national electric grid, instead they use candles for light, and they produce electricity with the help of wind and solar energy. Likewise, they have not joined the natural gas network, but rather they heat with wood from their own forests. The community is provided with water from the wells drilled next to each house and a shared 330 meters deep well at the village center. Waste-water management is done with a so-called root zone waste-water treatment system. They do not use chemicals in their farming and try to avoid them in household use as well. Whenever possible they use only animal and human labor power (that is to say, renewable sources of energy), at the same time, however,-especially in agriculture-for certain tasks that require great expenditure of time and energy, they rely on machines (e.g., tractors, excavators when large amounts of soil need moving, etc.). They aspire to food-self-sufficiency, and mostly succeed in this, in the areas of providing themselves with fruits, honey, and cereals.

The Eco Valley Project, which represents Krishna Valley as a sustainable community, i.e., as an eco-village, began in 2008 , and it integrated the religious tenet of simple life into the sustainability discourses prevalent at the time.

Although in this paper I do not wish to deal in detail with how Krishna Valley is viewed by the external world, ${ }^{7}$ these views are worth summarizing very briefly. What Krishna Valley means for the outside observer can be best grasped in the context of tourism as the supply (what Krishna Valley could offer) and the demand (the needs of the tourists) have mutually shaped each other, creating the main avenues for interpreting Krishna Valley. These are: (1) the exotic, which at first reading means India (the 'East') but can also be understood as referring to Krishna devotees; (2) the spiritual atmosphere, which can be seen as the Indian religion but also can refer to spirituality in the abstract; (3) leading a lifestyle that is close to nature, which refers to an environment friendly and sustainable lifestyle. Thus, Krishna Valley can equally be interpreted by and integrated into the expectations of those who are enthusiastic about India or the East, of religious seekers, as well as of those committed to a healthy lifestyle or interested in living ecologically (Farkas 2011).

The leadership of Krishna Valley is in charge of communicating with the external world and thereby has a great influence on how it is interpreted. They shape daily life and the main trends equally, and the inhabitants-in keeping with the teachings of their religion-accept their leadership. ${ }^{8}$ Leaders make their decisions democratically, which they then communicate to valley-dwellers as something quasi mandatory. The latter do have the right to express their opinions, but they rarely make use of it. Thus, if we are interested in what Krishna Valley means for the insiders, it is worth examining the meanings formulated by the leadership first.

\subsection{Eco Valley Project, Vraja Project}

Between 2009 and 2012, I saw two main trends taking shape, ${ }^{9}$ which can be seen as the reformulation - or according to its critics, separation —of the above-mentioned motto of "simple life and deep thinking". These are the Eco Valley and the so called Vraja project, i.e., the "projects" of voluntary simplicity and self-sustaining community and of a community living in constant sacredness, respectively. Although in theory the two cannot be separated since they both attempt to realize and communicate the founder, Prabhupadra's, conception of the Krishna conscious village, and the fact that, in practice, they are interpreted as two separate things can be seen in the reticence and cautious skepticism in connection with the Eco Valley project, which I encountered several times during my research. 
Krishna Valley came into being as a settlement for Hungarian Krishna-devotees, so that those among them who were able to adopt the-in Krishna terminology: "renounced" circumstances could live for their religion in a religiously homogenous community and in a natural setting that was conducive to tranquility. In 2000, declaring itself an ecovillage, Krishna Valley joined the informal organization that brings together Hungarian eco-villages, the Hungarian Living-Village Network. The Eco-village Foundation came into being in 2008, and the project has been flourishing since 2009. At the time, the notion of sustainability was increasingly gaining ground in both political and public discourses, and placing Krishna Valley in it was a conscious decision by the members of the Foundation. This interpretative process could come about relatively easily as the worldview of Krishnadevotees contains several "green" elements: thus, for example, they interpret nature as both being part of God and being God's creation, therefore its protection is considered to be a religious duty. ${ }^{10}$ They also personify the Earth (Bhumi devi), rivers (e.g., Yamuna devi), mountains (e.g., Govardhana), and worship them as such. ${ }^{11}$ The modest village life imitates the life of Krishna, as Krishna himself lived as a simple village boy at the time of his appearance in Vrindavana. Furthermore-as we saw earlier-the village came into being along the lines of the principles of Prabhupada, most of which fit right into today's more radical sustainability discourse (sustainable modes of agriculture, reduced consumption, frugal lifestyle, infrastructural self-reliance, self-sufficiency, etc.). Thus, we can say that Krishna Valley was overtaken by "eco-villagehood" at the beginning of the 2000s ${ }^{12}$ and from then on, they consciously continued to strengthen the eco-village aspects of the village (renewable sources of energy, the use of alternative technologies, the expansion of food self-sufficiency, etc.)

The Eco Valley project has gone beyond this and has made the passing on of (presenting and teaching) parts or the entirety of the eco-village or sustainable village model its task. Within this framework, they hold courses and workshops (both in Krishna Valley and elsewhere), and under cooperation agreements, they help the research of scholars and university students in the Valley. In the project, Krishna Valley serves as a model, through which those interested can practice and experiment with the principles of environmental, economic, and social sustainability and see the results; researchers can measure while the lay person can get to learn from the results of the experiments. ${ }^{13}$

The word Vraja in the eponymous project refers to the birthplace (Vrindavana) of Krishna and the broader venue of the first part of his life, the Indian region of Vraja (Uttar Pradesh State, $144 \mathrm{kms}$ south of Delhi). Krishna Valley's self-appellation for internal use, New Vraja-dhama ${ }^{14}$ indicates that it is a replica of one of the most sacred places, Vrindavana, of Krishna consciousness (see Farkas 2019). According to the teaching of Krishna consciousness, Vrindavana exists concurrently in the material world (India) and in the spiritual world. Where they adore Krishna (practice the religion actively), Krishna will appear, and not only he, but along with him, all his so-called constant companions (foster parents, brother, his cowherd companions, etc.), along with all of his sacred places, even Vrindavana. As the devotees put it: the sacred place will "manifest"15 or "go there":

"The place where people worship God and where people who live a pure life, the sacred place also goes there. Sacred place means that people practice a spiritual life there. Because bhaktas [Krishna-devotees] live here, and Radhesyama [the name of the divine statues on the altar of Krishna Valley], the holy place comes here along with Radhesyama and his bhaktas." (V. dd. 2011) ${ }^{16}$

"Krishna is here. If Krishna is here, then his companions are here too, and all the places where he pursues his pastimes. This is transcendental, because wherever Krishna is, his surroundings are there too. Krishna is manifested here, but then the surroundings are also manifest. And then here is Maharaja, and he has revealed what could be found where." (Kb. dd. 2011)

The Maharaja mentioned in the quote is a Hungarian leading pastor, Swami Sivarama. The Vraja project is his brainchild, he has "uncovered the sacred places of Vrindavana" in 
Krishna Valley, i.e., he transposed, in miniature, the sacred places of Vrindavana and its environs onto Krishna Valley and then they marked these places-among others_-with the characteristic maroon colored Indian-style pavilions. For ordinary visitors these are merely pleasant places of rest, but they indicate the most important places of the sacred map of Vrindavana (where some kind of Krishna-related event took place), and thus the Valley is a precise mapping of the most important sacred place of Krishna consciousness. At these places, according to the devotees, the so-called "pastimes" described in the holy scriptures, that is to say, everything that had happened to Krishna (for example his or his divine companion's birth), or what he or his constant companions had done (for example, his mother reprimands the child Krishna, his father herds the cows, Krishna slays a demon, etc.).

The Hungarian pastor started to write a book in 2006 in which he interpreted Krishna Valley as the mapping of Vrindavana. Meanwhile, he began the construction of sacred places. For a few years - starting in 2007-he conducted at least one pilgrimage per year to the sacred places (Nava Vraja Mandala Parikrama). ${ }^{17}$

Very little time passed between the launching of the two projects, and this may have contributed to the inhabitants' misgivings about them. Even more important was that the two projects were associated with the two main leaders of the Krishna congregation: the leading pastor and the president of the church (who at the same time was the president of Krishna Valley), and therefore-according to Magdolna Banyár- "the inhabitants felt that the two projects and the mentality behind them were rivals" (Banyár 2011, p. 258.)

\section{3. "Last Stop, Train Goes No Further"}

As I have indicated in the Introduction, the main goal of the paper is to show what Krishna Valley means to its inhabitants. ${ }^{18}$

This research question formulated earlier took on a new significance by the time the interviews were conducted in December 2011. By this time, it had become clear that the community-due to the new Hungarian Church Act had lost its status as an established church-and, as a result, stood to lose a substantial part of its lands, which threatened the very existence of Krishna Valley. ${ }^{19}$ As a result, Krishna-devotees called for a peaceful demonstration in front the Hungarian Parliament-for the day before I was to begin interviewing. Under these circumstances, the question of what Krishna Valley meant for its inhabitants became a much weightier question than I had originally intended. Several of my interviewees noted that there was no way to know what was going to become of them and whether what they were telling me would still be valid in a few months' time, i.e., whether Krishna Valley would still exist.

It became apparent quite soon that, in Krishna Valley, just as in any community one studies anthropologically, there was no single model, no two stories were alike, and there were no two identical paths that had led the inhabitants to Krishna Valley. Although some themes emerged during my conversations about people's attitudes towards life in the Valley, there were many individual stories and subtle differences in attitudes among these. I will present these themes through examining attitudes to the two components of the motto "simple life, deep thinking" and to the Vraja and Eco Valley projects.

The questions I put to my interlocutors targeted individual opinions and served to call forth personal stories. In the current paper, I will demonstrate what Krishna Valley means for its inhabitants and how they relate to the two interpretational frameworks available to them through individual interpretations. My sources are primarily the interviews I made with the inhabitants specifically on this topic, as well as the conversations I have had with them during years of field research. In addition, I have also used the results of a questionnaire survey conducted in Spring 2009.

"A." (an approximately 45-year-old, unmarried man, who resides in Krishna Valley in the house of unmarried men) was recommended to me in the planning stage of my research as one of the earliest Hungarian Krishna devotees-someone who has been living there since the very beginning. It soon transpired from our conversation that not only was 
he an old valley-dweller, but he was one of the first three inhabitants who set out to build Krishna Valley.

He moved to Somogyvámos at the request of Swami Sivarama in July 1993. He was basically a town person and had never intended to live in the countryside. Nonetheless, village life was not completely alien to him:

"that perhaps there is no electricity, or perhaps there is no piped water, well, in this house too, there is piped water right in front of the gate, in a hand pump well. But I already had had a taste of it because we were in India in February 1993 on pilgrimage. There one learnt what simple Krishna-conscious life was, when during parikrama we were on the road for a week, and there was no electricity and bathing from buckets with jugs. It helped a little bit to get into the mood here. So, the change wasn't so drastic that it would have caused a trauma to have to come here and no tap water."

Not long after moving to the Valley they bought a cow, soon the first calf was born, they began cultivating, and constructed the first temple-covered with polytunnel plastic. Then they began to build the temple and the first dwellings that he supervised, and he himself had put a lot of labor into. Besides paid craftsmen and unskilled laborers, during summers, Krishna-devotees arrived from all over the country to help. They lived in an old sheep barn left over from the time of the collective farms under socialism, sleeping on straw mats, washing in bathrooms constructed with polytunnel plastic covering.

"It was a nomadic life. Let me spare you the details, it would seem very nomadic, would not even come close to Brahminic standards [the strictest rules of cleanliness]." (laughs)

They continued practicing their religion during the construction in the simple polytunnel plastic covered temple, and just as others, despite the many hardships, he looked back on that period with nostalgia and-talking about bloopers-a sense of humor.

He worked for two years on construction, then he had many different kinds of jobs: he worked at the main kitchen, in horticulture, at the park department as he put it in the capacity of "grass- and woodsman". Most recently, he is in charge of the apiary of Krishna Valley. When asked what he liked and likes best to do, he answered: "dancing in front of the murti at the temple." Regarding what Krishna Valley meant for him, he replied:

"Last stop, train goes no further. There is not a prettier, better place where I could imagine spending my remaining lives. Years! That slipped out!" (A. d. 2011)

If not with such aplomb, but almost all Krishna-devotees responded to the question with similarly heartfelt sentiments:

"What does Krishna Valley mean to me? Everything!" (P. d. 2011)

“My life!” (S. dd. 2011)

"My life! I caught a glimpse on a photograph of Radhesyama, and they stole my heart. And then I knew that I wanted to do only this, and I wanted to live here, and I wanted to die here." (Rk. dd. 2011)

"Krishna Valley and Radhesyama are the center of our lives." (V. dd. 2011)

"What does Krishna Valley mean to me? Krishna Valley ... really, it is really true that in life the only eternal and real thing is Krishna. Because, because everything else is a transitory thing, with which we do not really have any deep, deep down we have nothing to do. When one comes to serve Krishna, that is perfection in life. Then, there is nothing but this. And this is what is in ... the spiritual world. Really, if someone can do this here, then he is already in the spiritual world. So, Krishna Valley is truly the goal of life, it is the spiritual world." (Kb. dd. 2011)

The devotees' responses to the hardships also become clear, for example from the remarks of this young woman who has been living in Krishna Valley for a year and a 
half, who, however-with a nice metaphor-immediately positions the meaning of the hardships within the interpretive framework offered by the religion:

"For us, this place is the place of our cleansing. Here every day is about paying homage to Krishna and for this very reason very often we must face great hardships, but we know that all this is a test that we must go through. For this very reason, at least from one point of view, life is happy here, because it is a wonderful place, but because here we are in a clinic where one suffers, because one is sick, therefore one suffers. But this is natural because suffering is part of cleansing." (Sz. dd. 2011)

As stated before, Krishna Valley was brought into existence to enable devotees to practice their religion in a denominationally homogeneous community, under circumstancesheld to be ideal for practicing religion-visualized by Prabhupada in his teachings about the ideal Krishna-conscious village. ${ }^{20}$ The fact that the religious homogeneity of the village was a tremendous draw for the devotees scattered all over the country can also be seen in the interviews and questionnaires. To the question "what are the three things you like best in Krishna Valley?" 21 of 34 respondents mentioned the company of other Krishnadevotees in their written response, and another three wrote the community of people with a shared goal. One of my interviewees did not hesitate when I asked her about whether she considered moving to Somogyvámos first or immediately to the Valley:

"No! Because I wanted precisely that there should be nothing that is not Krishnaconscious! I don't want to be associated with anything that is not related to Krishna-consciousness" (Kb. dd. 2011)

For example, she did not wish to see billboards, not even people who were not Krishnadevotees. She immediately added that she started "Krishna consciousness very fanatically". What-among other things—she found attractive in Krishna Valley was that

“they don't stare at me on the street if I am in a sari, and that I don't have to dress up to be treated as a human being. I was very happy to be [able to go out on the street] in snow boots, in a sari, in a cador ${ }^{21 "}(\mathrm{~Kb} \text {. dd. 2011) })^{22}$

It is worth considering the other responses to this question of the questionnaire (What are the three things that you like best in Krishna Valley?) The most frequent answers were: spiritual exercises (22), the company of Krishna-devotees (21), and the pair of Gods on the altar, Radhesyama (15). Eight respondents mentioned nature, five the guru, and the calm and spiritual atmosphere were cited by four respondents each. Prasadam (the food offering to God), a simple, natural lifestyle, the singing of the sacred name were each mentioned by three devotees, singing and dancing, fresh air, beautiful natural surroundings and the morning program were cited by two respondents each, and the cleanliness of the Valley, cooperation, similarity in values, leadership, community, sacred places, festivals, opportunities for preaching, a rural, self-sufficient lifestyle, and that the Valley was ideal for practicing Krishna consciousness had one mention each. It is clear from the answers that for the devotees, religious practices (spiritual practice), the community, and the murti-form of Krishna are the most important, and if we combine the responses naming nature, the natural environment with fresh air, beautiful landscape, and the rural, self-sufficient lifestyle, then the very "framework" of religious practice, the village and its natural environment become equally important for them.

The latter, however, does not mean that Krishna-devotees respect and love nature only for itself. The interviews provided the key to the Krishna conceptualization of the role of the natural environment and the rural lifestyle. We were having a conversation with one of the devotees about the methods and tools aiding religious concentration when she listed the village, the rural lifestyle among them: "You know, the village in itself helps this simplicity, that you can be serene." (Km. dd. 2011). Several other people made similar statements remarking that the peacefulness of the village, the simple lifestyle helped the mind to focus: 
in part with the calmness of nature itself, in part because it did not overburden one with information, impressions, and tasks held to be superfluous. ${ }^{23}$

"Consciousness is truly the essence of Krishna consciousness, Krishna Valley is a denounced environment where the mind can be calm [...] Because everything with which we are in assembly, is a seed in the heart. And they then start working there and begin to grow good or bad things. [...] If we see a beautiful temple from our window then the thoughts, the feelings, the will is different than when we look out and see something very attractive, then that can distract one's attention. The other thing is that life is simple, so one does not have to deal with anything. Only with serving." (Kb. dd. 2011)

The idea of not having to deal with anything extraneous when leading an austere lifestyle is contradicted by accounts that list the hardships of this mode of life, such as for example, having to do the laundry by hand, heating with wood, carrying water, getting up at dawn, and one devotee mentioned insects. An important question touched upon in the interviews was how they got used to life without certain creature comforts and altogethergiven that many of them were urbanites-to village life. Several of them explained the fact that - contrary to expectations - the transition did not present a great problem to them by reference to their earlier rural experiences (either that they were brought up in a village or spent summers with grandparents who lived in villages). Perhaps the oldest inhabitant of Krishna Valley, 68-year-old P.d. thinks of his life in the Valley as a logical continuation of his earlier life and attributes the ease with which he adjusted to life here to this: he was not attached to anything in particular in his earlier life either, he had no material desires, he was not interested in getting a larger apartment.

"When I first came here: there is no electricity? So, there is no electricity! You have to build a fire to have heat? You had to build a fire in my childhood as well, there was a tiled stove in the apartment."

One of his friends told him when visiting with him in the Valley that P.d. had already been a monk when he was still living in town. "And he was right!—reflected P.d.—Only I never noticed it!" (P. d. 2011)

Others regarded the hardships similarly to how they looked upon converting to Krishna consciousness and moving to Krishna Valley:

"But it did not cause any hardship, I accepted that this was how it worked." (Rn. dd. 2011)

"There was a time when for an entire month there was only zucchini. We hated it, but nonetheless when I think back, it was very very good! We knew that it would be zucchini, and that was that. And we were not daydreaming but concentrated on our service, on the tasks at hand." (Km. dd. 2011)

Yet others took the difficulties with a sense of humor: for example, several people spoke with a chuckle of how after first moving here for a while they were unconsciously feeling for the light-switch with their hand. Those speaking about the early days of building the Valley laughed at the missteps of their first efforts, for example the "anomalies" of cooking:

"There were these culinary "adventures" which were rather strange, they left a mark on one's biorhythm ..." (A. d. 2011) ${ }^{24}$

\subsection{Nature, Countryside, and Krishna-Consciousness}

The interpretation of the village, the countryside and nature from the point of view of religion goes beyond the pragmatism that looks upon them as tools for the focusing of consciousness and places Krishna Valley and its natural environment into a broader theological context. One of the most important aspects of this is that it interprets naturejust as the entire material world — as the creation, a part of and the possession of Krishna, 
the handling of which for this very reason puts a lot of responsibility on the devotees, which impacts farming, households, everyday life, and rituals alike.

In what follows, I show, with the help of excerpts from my interviews and questionnaires and life histories, how Krishna consciousness has influenced the thinking of the inhabitants of the Valley about nature.

$\mathrm{Kb}$. dd. (30-year-old, married woman, currently residing in Somogyvámos) came to know Krishna-devotees as a 14-year-old inhabitant of a rural town in 1994. She found the message of Krishna consciousness, but she did not want to commit to it yet, rather she wanted to enjoy herself. At the age of 18, she realized that, although she had tried many things, she saw no point in anything other than Krishna consciousness. It was not that she had had bad experiences, but rather it was Krishna consciousness that could convincingly explain to her what life was what the meaning of existence was. At the age of 18 , she committed herself to the religion, and from then on, she lived as a temple bhakta and a book distributor. She visited Krishna Valley on the occasion of various festivities, where she came to realize that it was really only there that she could live her religion fully. On the one hand, she was attracted to the rural lifestyle, on the other, she thought that Krishna-devotees there were more "advanced" than others in a spiritual sense. In addition to the company of devotees, the murtis on the altar of Krishna Valley were also of great attraction to her, as was the fact that her guru lived here. She decided to move there, but because she was very good at her job, they did not really want to let her go. As a result, she cried a lot, prayed a lot, and always sang a song that was about "let us live near the Lord". Soon thereafter, at the age of 20, she was able to make the move to Krishna Valley. She enjoyed life very much here:

"Seriously, I enjoyed that you had no light switches, that there were no ugly sockets and wires in the corner, and I adored it that you could make a fire in a tile stove. [...] I could live simply, I got up in the morning and I could immediately recite her mantra, stepping out the door, the first trip could lead to the temple. Simple life, carrying wood, washing by hand. I loved all of it very much."

She was the one who was happy that only Krishna conscious things surrounded her. She claims that her relationship to nature has decidedly changed since living here. Yet, the relationship to nature was not without precedent in her life as her grandparents had been gardeners, her mother a landscape gardener, but they could never get her into gardening, and she was simply not interested. She lived in a town, the brand of her clothes, the newest technical gadgets, money, partying interested her, but she was not at all into nature. However, when she moved here:

"you see it automatically, I began to notice the orchard in springtime, I see how beautiful these flowers are. To live in the middle of such a beautiful place, nature displays its beauties. You notice, even if you did not notice it before."

She enumerates the birds, the beautiful storm, the stars, the moon, things that never claimed her attention in town. It makes her happy to swim, not in a swimming pool but in a clear lake, to dress under a willow tree, not to have to pay for a ticket, not to have to wear that "stupid swimming cap." "Nature made me pay attention to it" she concluded.

After arriving to Krishna Valley, she first worked in the kitchen and then-in a strange twist of fate and basically by accident-she became a gardener. Earlier, she used to string flowers a lot because she loves to make a garland for Krishna (they make a new garland for the murtis of the altar every day, which I have found to be a very popular activity among devotees). During a walk, she chanced upon an abandoned rose garden. The rosebushes were overgrown with tall weeds, but she could still see what a treasure the garden was hiding. She wondered why they were buying the flowers for Krishna, "when these were beautiful, fragrant, fresh, and real." Wading through the sea of weeds and thorns she picked the roses, strung them as a garland, "and when it was time to greet the murtis I saw that this was what I needed to do." In addition to economic reasons, she justified this as follows: 
"... on the other hand, I sensed this connection to Krishna, to Radhesyama very keenly. What a beautiful connection: to grow the flowers for them and to offer them up. And this affected me very strongly, and I begged to be allowed to do this."

Then she worked in as a gardener for 7 or 8 years, returning after a long detour, to the profession of her grandparents and parents.

A. d. who has been introduced earlier and has lived in the Valley since the beginning, since 1993, does not consider himself to be a "sentimental nature lover, who hugs trees or adores deer", nonetheless, a few years ago while on a walk, he discovered a beautiful place in the nearby forest which completely enchanted him. He immediately placed the aesthetic experience into the interpretative framework of his religion:

"That place helped me realize what a tremendous imagination the creator had, what his creation was like. How diverse and marvelous it was. So, I have become a bit attached to that place. [...] When I saw the beauty of this place, then I knew, I figured it out that this was Krishna's energy, and how wonderful it was that it did not merely exist and have beauty, but I could also associate it with somebody. It gives me a plus that I can relate it to Krishna. I don't know, it gives a kind of ... Whatever is beautiful in the world, then it can be related to Krishna. Then one can appreciate and praise his beauty. And love it. And then we can come to love him through these sights and experiences. This is the essence of bhakti yoga, and as we bring our love towards Krishna, then through these tiny instances it can be done. The more one loves Krishna, the more one will love one's environment and also this manifestation through nature. These wonders of nature." (A. d. 2011)

Not only did A. d. place the beauty of the spot he loved so much and the joy this beauty gave him within his personal relationship with God, but later in the conversation, he also defined the relationship of Krishna Valley, Krishna, and the main murtis: on the one hand, the task of Krishna Valley is that "it should be a worthy dwelling place for the Lord," on the other hand, "Radhesyama turns Krishna Valley beautiful, their beauty shines throughout the Valley". ${ }^{25}$

$\mathrm{Km}$. dd. is also one of the earliest inhabitants and is happy to reminisce about the early days. As we have already seen from A. d.'s account, the living conditions of the first settlers were indeed very simple: they lived in sheep barns, slept on straw, had "showers" from a bucket in makeshift polytunnel "bathrooms, their temple was also a polytunnel structure." Because of their limited means, they were trying to grow part of their own food. Although due to their inexperience, many problems arose (an enormous amount of zucchini that went bitter, corn harvested too late in freezing temperatures, an overabundance of Jerusalem artichokes, etc.). For Km. dd. however, this still opened new dimensions in her relationship to the land, nature and Krishna:

"We ate sitting on the ground, we had a simple temple, there were one or two pictures, a small altar, but for everyone this simple life was a great experience somehow. There were times when we had deep fried dough and tomatoes for breakfast. There were times when we ate melons directly from the land. And we felt that all of this was given by Krishna. We learnt that the land feeds us. And then you were happy to work. Digging potatoes, picking carrots, hoeing, were hard but when the fruit was already there, you really had everything [...] It is true that I too was a city girl, but I liked these renounced things, because they gave you strength, purity, they made you pure." (Km. dd. 2011)

Later, she also interpreted the above from the point of view of the soul imagination of Krishna consciousness:

"You know, those who do not believe deeply, they only see food in these things. Krishna-devotees, however, are always aware that whether it is a carrot or a cauliflower it is a soul in a body, and then according to our thinking, we can 
receive it when we offer it up. So, primarily these belong to God, and when we make the offering that's when we are able to enjoy it. This is an important thing because then we are able to appreciate the little things, too. And basically, you know, the Earth is also our Mommy the Earth, Earth Mother, among our seven mothers she is the most important, she is the one who provides us with all kinds of things. She grows the grass, so that the cows make milk from it. So, there is a person behind everything, and this is no different with plants, minerals, stones, the earth. Behind all of this, is one person, and then, because we learn the culture of respect, we look at these things completely differently. [...]

We live together with nature, you know. I too ride my bike in the village. It happened to me that the branches of a willow tree were bent over the road and as I passed it by it brushed me gently [she demonstrates how the branches caress her], and then I said: Hare Krishna, thanks. Yes. Then you know, we read the holy scriptures, for example, about how patient trees are, this is their most notable characteristic. And by God!, really, they can stand there!" (Km. dd. 2011)

I thought it important to cite the statement about the holy scriptures, because it calls attention to a significant factor shaping the worldview of Krishna-devotees: the role of studying the holy scriptures. $\mathrm{Km}$. dd. too points out the significance of this in the same conversation: "Although they [plants and animals] cannot speak, they do feel, and we have to be able to see this. If for no other reason than through vedic knowledge, that you read it and then you accept it, that he too is a soul." (Km. dd. 2011) ${ }^{26}$

"And they have a good place. Because they are respected, honored" she adds. In other words, plants and animals also are in a good place in Krishna Valley, because even though, according to the beliefs related to reincarnation, they move on an automatic spiritual evolutionary path in the series of births, i.e., they do not merit being born in the Valley, nonetheless they clearly are in a good place here. That they think that religious practice affects nature is shown by the fact that some people recite their mantra to ensure a larger harvest. The garland of flowers taken from the altar, and therefore endowed with a cleansing power, will also cleanse its environment when placed into nature.

This kind of thinking specifically influences everyday practices, for example, household activities or gardening.

"The other thing is, that this is Krishna's energy. You should not waste. For example, when I am watering. Or we have to compost, not only because it is biologically beneficial, but also because I must not waste. And if I put it in a certain place, then Krishna devised it in such a way, that it should be recycled and feed the soil." (S. dd. 2011)

"We are always conscious, that everything belongs to Krishna, and then you do everything with that in mind, that is how you maintain things, how you clean, how you do the washing, how you cook. It is your home, but still, it is also Krishna's home." (Km. dd. 2011)

The image of the Krishna devotee who recites her mantra over the plants, points to a different aspect of the relationship of the natural environment and Krishna Valley. The devotees think that religious practice in the Valley affects nature, on the place: it cleanses it in a ritual sense, which renders it a sacred place. The essence of this is, as we have already seen, that wherever service to Krishna is seriously practiced, Krishna will come, and the fact that he-and his companions-have moved here made Krishna Valley a sacred place. At the same time, strict religious practice also cleanses nature:

"Besides, the purity deriving from spiritual life will extend to its environment too, and because it is also an Eco Valley, it also appears on a physical level. If we look at it more deeply. So, this organic agriculture is also a kind of purity, the environment becomes automatically purer. So, this need also appears on such a physical level." (Rn. dd. 2011) 
According to my interlocutors, there are multiple interrelationships between religious practice and organic agriculture, they influence each other in complex ways, and religious practice-by having brought Krishna here-exerts a purifying influence on all aspects of the material world, and conversely: the "clean" functioning (organic agriculture) of the material world exerts its influence on the purity of the Valley at all levels.

Rn. dd. included the Eco Valley project into her Krishna Valley interpretation, but this is rather unusual. As I mentioned already, in recent years being an eco-village plays an important part in how both Krishna Valley and the tourism it attracts are conceptualized and communicated, nonetheless, during my fieldwork, I found that in the thinking of Krishna-devotees living in the Valley, Krishna consciousness takes precedence over environmental ethics. For them, their lifestyle is simply following the norms of their religion. Even for those who understand and see these connections, religion is primary, and the interpretative framework of the ecological lifestyle (and its communication) is provided by their religion, as is the cohesiveness of the community:

"We don't refuse to use, for example, chemicals in agriculture because they go into the carrots that we eat and poison us, too. Rather, it is because, for us the earth is Bhumi devi, a person, and the water and the air are also persons whom we do not wish to coerce. Bhaktas, Krishna-devotees are not environmentalists." (Questionnaire 2009)

Krishna-devotees think that a merely ecologically aware worldview is not enough for sustainability, and they consider their sacred scripts-which they also interpret as instruction manuals for life-to be expressions of the eco-conscious lifestyle.

"In any case, a fully realized eco-conscious attitude cannot be maintained in the long-run without a God-centered worldview. The latter fully realizes the partnership created with planet Earth. The ecological worldview should not and cannot be separated from the instructions of the one who is most knowledgeable about creation. God's instruction manual regarding our planet is from the beginning eco-centric." (Questionnaire 2009)

Moreover, some think that Krishna and his life is the "most eco."

"In the spiritual world Krishna lives in an eco-village. Environment-friendly means that you live in a Krishna conscious way with Krishna."

"The way the spiritual world works is a perfect example of the simple life."

"Krishna also lives naturally, this is why he is so attractive (among many other things)."

"Krishna has many names, according to his characteristics. He is also the most eco."

"Krishna is eco-conscious from the beginning." (Answers from the Questionnaire 2009)

\subsection{Eco Valley, Krishna Valley}

The Eco Valley project-as mentioned earlier-led to doubts and misgivings, at times it gave rise to explicit resistance. Besides everyday conversations, there were examples of this in the answers to the questionnaire. There were three kinds of reactions to the question "what is your opinion about the fact that some people under certain circumstances refer to Krishna Valley as Eco Valley?": agreement, disapproval, and a cautious or laissez faire response. Those who were in agreement, almost without exception, interpreted the Eco Valley project as a tool of missionizing (preaching). Some examples from among these:

"If it helps preaching it is good."

"Good preaching."

"In preaching this is natural, and it is proper." 
"We can take them to Krishna through this too."

"My opinion is the same as what Prabhupada had said: 'preaching is the most important thing', and if this is how you can draw somebody's attention to Krishna Valley, then so be it."

"It is as good as preaching."

"A clean, calm environment is favorable to spiritual life, because it favors God (Krishna is eco-conscious from the beginning)."

The answers of those who disagreed with it were as follows:

"They could be more daring they could call it Krishna Valley."

"I think it pushes the religious side to the background a bit. The farm is first of all a sacred place, New Vraja Dhama, Radhesyama's home, and only Eco Valley in second place, perhaps this is not emphasized enough."

And a cautious response:

"As long as it is done for the sake of the Lord, it's fine."

The answers demonstrate quite clearly that Krishna Valley has another important aspect, another way it can be interpreted that I have not emphasized so far, that is its role in missionizing. The Valley in its entirety wishes to present a functioning, viable model of the theocentric community, based on religion, and wishes to provide an opportunity for those who arrive here to encounter God and religion. This is what gave rise to the first negative reactions and fears in connection with the Eco Valley project: these devotees felt that what was the most important to them, Krishna, and their religion, was put on the backburner.

At its beginning, one of the goals of the Eco Valley project was to carry out internal training, that is to say, teaching ecological thinking and practice to valley-dwellers. Eventually, on the level of training, this did not take place either: the inhabitants learnt those practices of bio-gardening and eco-conscious householding that they found useful and practicable for themselves from each other, from their neighbors and the gardeners of the Valley-and they still do not call them eco-conscious but rather refer to them with the terminology of the Krishna movement ("renounced", "simple".) Based on my 2009 questionnaire survey, it is clear that the concept of renewable energy is not always clear to the devotees who otherwise use wood for their daily fuel needs. In practice, environmentally friendly methods and tools are more and more widespread (for example, ever since the root zone waste-water treatment system has been put into service, they pay much more attention to using bio-degradable, eco-friendly cleaning products), and the number of gardens around dwellings has noticeably increased. Therefore, it would be an undoubtedly interesting question whether the ecological way of speaking that has gained strength in the official communication of the Valley has had an effect in this and whether ordinary valley-dwellers place their lives within this ecological discourse? From my conversations with them, it seems that only very few of them do:

"JF: In your opinion has the Eco Valley project had an effect on bhaktas? On how their conceptualization of nature, of renounced life?

$\mathrm{Kb}$. dd. (signals that she does not understand the question.)

JF: Krishna Valley has become an eco-village. Does this affect everyday life?

$\mathrm{Kb}$. dd.: I don't think this is in focus that much.

JF: So, it's all the same for the bhaktas?

$\mathrm{Kb}$. dd.: Well, because in any case ... That it is called Eco Valley-it has always been that! So, this preaching is for the outside. It is not a very noticeable thing here, because it is so anyway." (2011)

As Krishna Valley is primarily New Vraja-dhama for its inhabitants, it is not surprising that they speak more enthusiastically about the Vraja project, and although some have 
told me about the theological meaning of village life and simple lifestyle, it seems that the recognition of sacred places ${ }^{27}$ as tools of religious practice is stronger. As I have noted before, Krishna-devotees find it very important to focus their consciousness on Krishna and, therefore, the elements that help them do this are important parts of religious practice, thinking about the life of Krishna has a prominent role in this. In keeping with this, the sacred places designated in Krishna Valley-since all of them are associated with an event in Krishna's life-are also interpreted as devices of external help, as tools:

"This is also the essence of Vrindavana. If someone goes on a pilgrimage then the important thing is that we should be able to remember Krishna, the pastimes that he engaged in at that place. And similarly, here at Krishna Valley if you go to these places you can meditate on these pastimes. Or you can experience the special nature of that place. [...] Earlier it was just a stream, but now the pavilions are there and when you pass it by, you can see that Krishna was born there, and he was a child here, and then it is easier to think of it." (Tv. d. 2011)

As the last sentence shows they also reinterpret nature within the framework of the "sacred place" concept, thus placing it into another interpretative frame: the stream, the hill, and so on, are not simply the property and part of Krishna, but also constitute part of the spiritual world that is descended here, where the events of Krishna's life are taking place continuously. This is as if the devotee walking around in the visible Krishna Valley were concurrently walking in another reality, among events taking place in the spiritual world. At the same time, she has no personal experience of this (she cannot see it), she only has her knowledge and her faith reinforced by her knowledge, with the help of which she believes that what she has learnt is what is taking place at the sacred place. ${ }^{28}$ She can use this knowledge in her religious practice (she thinks of what has happened/what is happening there, and with this, she focuses her consciousness on Krishna) with the help of which she gets closer and closer to what Krishna Valley means for most of them (her life's goal, its meaning, its center, the last stop, the place of cleansing, etc.).

When I asked valley-dwellers about their favorite places, most of them named the shaded grove on the bank of the brook which they identify as the Jamuna River in India and the lakes created by damming it, or the so-called Kaliya-ghat where Krishna had slayed the snake demon called Kaliya. They usually pray or read here, but there was one devotee who-weather permitting - made a prayerful pilgrimage (parikrama) to all the sacred places. The place she visited the most was a sacred place at some distance from the beaten path walked by the tourists, placed on a hillside, reaching it could also be considered exercise. Keeping a distance from the tourists (escaping) came up in several conversations: an elderly woman told me with a laugh about how she tried to climb the hill to the same far-away place which made her even more of a tourist spectacle: she was even more noticeable in her snow-white sari on the hillside far from the temple than if she had sat down among the other devotees near the temple. A young woman who finds that the many tourists and festivals and the intensity of life from spring to fall present one of the greatest hardships of life here-has confessed to me that she sometimes escapes to the so-called Pusztatorony (the ruins of an ancient church) on the outskirts of Somogyvámos "because there is not a soul there, and it is so quiet that it is unbelievable!" (Sz. dd. 2011).

By creating the sacred places, the number of special venues for religious practice have multiplied in Krishna Valley: in addition to the temple, room these places also have a surplus of sacred potential, and therefore they are especially suitable for meditation, prayer, or the reading of the sacred scriptures. The cleaning up of sacred places, tidying them up (dhama seva-serving at the sacred place) also brings "spiritual development, spiritual results": "You can get a lot of credit in your spiritual bank account if you serve these sacred places. What is more, you serve Radhesyama." (V. dd. 2011)

At the same time, in a certain sense, sacred places also need devotees. Already in the first quote, explicating the "arrival" here of the sacred place contained a sentence that referred to this: "Sacred place means that people practice spiritual life there." (V. dd. 2011) Another devotee tried to make me understand the essence of Krishna Valley, thus: 
"The sacred place is manifested where God is adored. But for that it is necessary to have people who go there and perform spiritual practices and then it can manifest itself more intensely." (Rn. dd. 2011) ${ }^{29}$

Krishna, his companions, and the sacred place then go to where the devotees of $\mathrm{Kr}$ ishna are, and with their spiritual practices, the devotees hold on to and even strengthen the sacred power of the place. Furthermore, an active religious practice helps in understanding sacred places and promises, in the long run, the glimpsing of events taking place in the spiritual world in Krishna Valley. If the devotee neglects his religious practice, his vision will be clouded, he will not understand, not sense the sacredness of the place, and will have hardships in all aspects of his life. When speaking about Krishna-devotees who had left the Valley, people try to interpret in general why they had moved away. One of the possible reasons suggested is that the devotee in question had neglected his religious practice and, as a result, had to face increasingly more serious hardships, which made him back off. Another reason given is, precisely, the lifestyle is one that not everyone can get used to. In any case, Krishna does not make it any easier for his devotees, and from the majority of the narratives, it even seems that he purposely puts obstacles in their way to test their faith:

"Those bhaktas who live here, Radhesyama pays even more attention to them, he tests them mightily, tries to see how much they really want him. In this regard, life is not easy here. This can also be seen from the fact that there is a lot of fluctuation in the population." (Sz. dd. 2011)

The sensing of this special attention was quite clear from all conversations, and there were also numerous indicators of a personal relationship to God: Krishna-devotees speak about Radhesyama as if he were an individual truly living among them, and they relate to him as if he were one of their neighbors. Thus, for example, they pay him frequent visits (at the altar), they come to see how he is dressed that day, what kind flower garland has he been given, they speak about his mood that day, they take the first harvest of fruits to him, etc. Krishna, who lives there with them, is an intrinsic part of how they think about Krishna Valley. However, their presence and active practice of their religion are also necessary for the well-being of Krishna and for the sacredness of the Valley.

For its inhabitants, Krishna Valley then means, primarily, the abode of the New Vraja Dhama Krishna, as well as the company of people of the same religion and the place of, and opportunity for, the perfect practice of their religion. Their lifestyle, the natural environment, and village life provide a framework that they understand to be a tool from the point of view of their religion. This, however, does not mean that they do not see its beauty or do not value its calm and peacefulness. Indeed, it is precisely interpreting it through their religion that makes it truly precious to them, and it is through this that Krishna Valley has become the goal, meaning, and final stop of their lives.

\section{Conclusions}

The Hare Krishna movement, represented by the ISKCON church, is one of the most widely studied new religious movements. The links between religion and nature and religion and environmentalism are currently "hot topics" with numerous works focusing on Hinduism. We may ask then if there is anything new one could say about these subjects: is there something we still don't know about the Hare Krishna movement or about Hinduism's approach to nature?

This paper is a case study approaching this subject from a micro-level perspective: we learn the answers through the members of a Hungarian Krishna community. The research producing material for this study started with one simple question: What does Krishna Valley, your place of residence mean to you? The answers to this single question reveal individual life stories and outline individual ways of experiencing Krishna Valley. It is important to note, though, that these answers were recorded in a specific local and global context and should be interpreted within this context: they are answers to global issues by an Eastern European, Hungarian, rural vaishnava community belonging to an 
international movement. We must also note that these individual interpretations were also influenced by the peculiar situation this community found itself in at the time of the research. In this story, micro-level reactions reflected on the macro-context at several levels: individuals reacted to the competing interpretations of their settlement, and a local community reacted to global processes. My paper contributes to the better understanding of the Hare Krishna movement by showing how it operates in the 21th century at the level of an Eastern European small community and how this small community responds to global dilemmas. By presenting a western vaishnava community's practical approach to nature, it also contributes to the subject of Hinduism and nature.

Krishna Valley is the residence of a group of Hungarian Krishna believers, a religiously homogenous settlement and sacred place for its residents where they lead a modest, religious life devoted to Krishna. Krishna Valley is thus New Vraja Dham. The village could operate as an eco-village precisely due to this modest lifestyle, which affiliated its residents not only with a new global trend but also with a new interpretational framework. Krishna Valley is thus also the Eco Valley eco-village. The coexistence of these two interpretations should not be problematic, but in that specific time it was: besides conforming, synthesizing attitudes voices of anguish and resistance also emerged. The quick and radical development of the Eco Valley-project, and its communication to the external world and the community, raised concerns over the nature of the village: is it a sacred place or an eco-village? New Vraja Dham or Eco Valley? This question is a complex one since the link between nature, man, and God-being inherent in the Hindu worldview-is also significantly present in the Valley's interpretation as a sacred place. The research has shown that this religious interpretation comes before environmental ethics, and for villagers, leading an ecological life primarily means living according to the rules of their religion. This dilemma about the essence of the Valley has since been mostly resolved. This study has, nevertheless, contributed to our understanding of how a small community and its members experience and reflect on global processes and what interpretative strategies help them position themselves, their religion, and their community within these processes.

Institutional Review Board Statement: Not applicable.

Informed Consent Statement: Informed consent was obtained from all subjects involved in the study.

Data Availability Statement: The data presented in this study are available on request from the corresponding author. The data are not publicly available due to privacy issues.

Acknowledgments: Thanks to all Krishna devotees who helped in the writing of this paper.

Conflicts of Interest: The authors declare no conflict of interest.

\section{Notes}

By eco-conscious elements I mean elements of lifestyle that aim to do as little damage to the natural environment as possible (environment-friendly methods in architecture, handling of waste, water treatment, husbandry, household, transportation. Reduced consumption, voluntary simplicity, recycling etc.).

2 As I mentioned, when I was gathering material for the current paper, Krishna Valley was in special situation. The time of radical change in a community is always exciting for anthropologists since it reveals group dinamics. This period helped me better understand the Hungarian Krishna community in many respects. Since then the processes discussed here have settled and contesting conceptions aiming to define the valley have reached a balance.

3 On the topics of Vaishnavism, succession of Vaishnava disciples and Caitanya see among others: (Bhattacharya 1995; Clooney and Stewardt 2004; Dandekar 1987; Farquhar 1998; Purusatraya 1993). On the relationship of Hinduism, Vaishnavism and ISKCON see Flood (1995).

4 Except for the short, transitory period at the beginning of 2012 when the so-called new Church Act (Act CCVI of 2011 on the right to freedom of conscience and religion and the legal status of churches, denominations and religious communities) was being debated and modified in Parliament. On the history of the Hungarian Hare Krishna movement, its basic teachings, and institutional framework, see (Kamarás 1997, 1998; Farkas 2004, 2009, 2020a). For the most recent overview of the European presence of the movement see: de Backer (2020). 
5 See Jnana 1994. On rural Krishna communities, see: http://centers.iskcondesiretree.com/farm-and-rural-communities/ (accessed on 5 April 2021), Lestár (2018), Lestár and Böhm (2020). On the first rural Krishna community (New Vrindavana, USA) see Sanford (2015).

6 Lands that had become avaliable for sale due to the pos-socialist reorganization of land-ownership.

7 I have presented these in an earlier work, see Farkas (2011).

8 This is based on the so-called authority system and its religious legitimation, see Broo (2003), Farkas (2009, pp. 97-127).

9 My hunch was reinforced by Magdolna Banyár's PhD-dissertation that she had completed in the meanwhile. She is a Krishna devotee and the Rector of Bhaktivedanta College, Banyár (2011, p. 258).

10 See: "Hindus speak of the cosmos (including the stars, the atmosphere, the earth, plants, animals, and humans) as God's body. Since everything is divine, an ethic of reverence and respect is demanded from humans toward all other manifestations of God's body." (Coward 1998, p. 40). Klaus Klostermaier sees the Vaishnava bhakti tradition as a resource for the solution of contemporary ecological problems. (Klostermaier 1991). For the commentaries on Bhagavadgita (especially 6.29.) and their understanding with the environmental interpretation see Jacobsen (2000). The protection of nature as religious duty is also present in other religions, see for example: Gottlieb (2003, 2010), Taylor (2010), or see Pope Francis' encyclical (2015) entitled Laudato si.

11 Krishna believers' above mentioned conception of nature resonates with tenets behind Hindu ethics of environmentalism (see Framarin 2011, 2012, 2017; Nelson 1998). Although the religious philosophical validity of these views has been questioned by many (see Framarin 2011), these scientific dilemmas are irrelevant for the average western Krishna believer.

12 The case of Krishna-Valley is not at all exceptional: the first and largest eco-villages were originally spiritual-religious village communities, such as for example Findhorn in Scotland, or Auroville in India, or the Estonian Lilleoru (see Bina 2014; Kalantzopoulus n.d.; Koziol 2020; Rigby 1974; Tamm 2009).

13 On this, see: https:/ / ecovalley.hu/ (accessed on 5 April 2021).

14 Vraja-Vrindavana and its environs are dham-sacred places.

15 Manifest means: appear, pervade, enspirit. For enspiriting process see Studley (2019).

16 At the end of interview excerpts I provide the initial of my interlocutor (received at initiation), the notation $d$. refers to a male (dasa) and $d d$. to a female (devi dasi). In the case of names beginning with the same initial, I add a second letter from the name, e.g., Radhakrisna dasa-Rk. d. The four-digit number indicates the year when the interview was conducted.

17 In a previous paper titled "From Krishna Valley to New Vraja-dhama" An Example of Tradition and Innovation in Gaudiya Vaishnavism I have shown the practices and interpretative processes that transformed Krishna Valley into a sacred place mirroring Vrindavana (Farkas 2019). This process is called mandalization in literature, see among others: (Grapard 1982; Smyer Yü 2015; Vemsani 2016). "Last stop, train goes no further." This is a well-known advertising slogan from 1980s Hungary. In this case it means finding life's ultimate purpose.

19 Thanks to the subsequent (March 2012) modification of the Church Act the community of Krishna-devotees could keep its status as an "established" church.

20 Briefly (based on Jnana 1994): The ideal Vedic civilization, its social system, husbandry, art, institutions, education, etc. has to be realized in independent village communities. For this to happen the first and fundamental condition is the creation of self-sufficiency.

21 Cador: a multifunctional warm piece of cloth: they may wrap it around the body against the cold or sit on it on the cold ground, etc.

22 The same devotee no longer lives in the Valley, but rather outside it, in Somogyvámos, and she explains this quoting her changed circumstances and her age: "A child [she is referring to herself] when she moves to Krishna Valley, I was 20 at the time, she can afford to be a fanatic, but when one is an adult, then there are other things besides the world of fairytales." (Kb. dd. 2011).

23 It resonates with Tibetan Buddhists' worldview, who view nature as an ideal symbolic locale to pay their respects to Buddha. (see Studley 2019).

24 Of course, the picture would only be truly complete if we had the opinions of those who had left both Krishna Valley and Somogyvámos, however, the research did not extend to them. Among my interlocutors there were some Krishna devotees who lived in Somogyvámos, but they did not leave the Valley because of the physical hardships of the lifestyle (rather they had family reasons, which there is no space to discuss here.) At the same time, all of them thought that for example washing machines were a convenience (everybody put washing by hand in first place when listing the hardships of life in the Valley,) but a young couple felt that if the often mentioned ecological, economic collapse were to come and there were no electricity, they-because of their earlier practice-would be able to adapt to the new situation any time.

25 The seemingly contradictory use of the singular and the plural (Radhesyama makes Krishna Valley beautiful, but their beauty-is explained by the fact that Radhesyama is the name of the pair of murtis on the main altar of Krishna Valley, and the devotees when they speak about Radhesyama despite the two figures they usually use the singular: thus, for example the grace of Radhesyama and not of the Radhesyamas. Or: "I feel that Radhesyama is personally watching over us." (Rk. dd. 2011). But, as the above quoted sentence shows, the mixing of the singular and the plural form within even the same sentence is common. 
On the relationship of faith and knowledge in Krishna consciousness see Farkas (2020b).

When I refer to sacred places in the plural-following the usage of Krishna devotees-I am referring to places that denote "replicas" of the sacred places in Vrindavana in the Valley.

28 I found it very interesting (and worthy of further reflection) how a young married woman explained the relationship of faith and knowledge in relation to sacred places: "If somebody believes in it, it means that she knows. I believe it because I know what happens here [at the sacred place.] Faith is a conviction, and this kind of faith is also based on knowledge. That we know what is here, and often, it strengthens the faith if there is knowledge beside it. The more I read about it the more I can develop [my faith], the stronger my conviction becomes." (V. dd. 2011). On the relationship of faith and knowledge, see Farkas (2020b).

Here "manifest more intensely" means: it pervades, enspirits Krishna Valley even more.

\section{References}

Banyár, Magdolna. 2011. Krisna társadalma. Max Weber Hinduizmus Koncepciójának Társadalomtörténeti Alkalmazása. [Krishna's Society. A Social Historical Application of Max Weber's Conception of Hinduism]. Ph.D. dissertation, Eötvös Loránd University, Budapest, Hungary.

Bhattacharya, Sunil. 1995. Vaishnavism in Eastern India. Calcutta: University of Calcutta.

Bina, Bhatia. 2014. Auroville: A Utopian Paradox. New York: Columbia University Academic.

Broo, Mans. 2003. As Good as God. The Guru in Gaudiya Vaisnavismus. Abo: Abo Akademi UP.

Clooney, Francis X., and Tony K. Stewardt. 2004. Vaisnavism. In The Hindu World. Edited by Sushil Mittal and Gene Thrusby. New York: Routledge, pp. 162-85.

Coward, Harold G. 1998. The Ecological Implications of Karma Theory. In Purifying the Earthly Body of God: Religion and Ecology in Hindu India. Edited by Lance E. Nelson. Albany: SUNY Press, pp. 39-49.

Dandekar, Ramchandra Narayan. 1987. Vaisnavism. In The Encyclopedia of Religion. Edited by Mircea Eliade. New York: Macmillian Publishing Company, vol. 4, p. 171.

de Backer, Luc. 2020. The Hare Krishna Movement in Europe. In Handbook of Hinduism in Europe. Edited by Knut A. Jacobsen and Ferdinando Sardella. Leiden: Koninklijke Brill NV, pp. 462-527.

Farkas, Judit. 2004. The Role of the offered food in the life of the Hungarian Krishna-believers. Food and History 2: 283-301. [CrossRef]

Farkas, Judit. 2009. Ardzsuna Dilemmája. Reszocializáció és Legitimáció egy magyar Krisna-hitú Közösségben. ["Arjuna's Dilemma." Resocialization and Legitimation in a Hungarian Krishna-Community]. Budapest: L'Harmattan.

Farkas, Judit. 2011. India magyarországi mosolya. Ellenvilágok és élménymodellekp árbeszéde Krisna-völgy ökofalu turizmusában. ['India's smile in Hungary.' Dialogue of counterworlds and experience-models in the tourism of Krishna Valley]. In Szinre vitt helyek. Tanulmányok. Edited by Zoltán Fejős. Budapest: Néprajzi Múzeum, pp. 62-81.

Farkas, Judit. 2019. "From Krishna Valley to New Vraja-dhama" An Example of Tradition and Innovation in Gaudiya Vaishnavism. In Present and Past in the Study of Religion and Magic. Edited by Ágnes Hesz-Éva Pócs. Budapest: Balassi, pp. $213-28$.

Farkas, Judit. 2020a. Hindu Groups in Hungary. In Handbook of Hinduism in Europe. Edited by Knut A. Jacobsen and Ferdinando Sardella. Leiden: Koninklijke Brill NV, pp. 1060-80.

Farkas, Judit. 2020b. "I believe in it because I know". Faith and Knowledge in the Lives of Hungarian Krishna Devotees. In Faith, Knowledge and Doubt in Religious Thinking. Edited by Vidacs Bea and Pócs Éva. Budapest: Balassi Kiadó, pp. 395-410.

Farquhar, John Nicol. 1998. Modern Religious Movements in India. Delhi: Munshiram Manoharlal Publishers Pvt. Ltd.

Flood, Gavin. 1995. Hinduism, Vaisnavism, and ISKCON: Authentic Traditions or Scholarly Constructions? ISKCON Communication Journal 3: 5-15.

Framarin, Christopher G. 2012. Hinduism and Environmental Ethics: An Analysis and Defense of a Basic Assumption. Asian Philosophy. An International Journal of the Philosophical Traditions of the East 22: 75-91. [CrossRef]

Framarin, Christopher. 2011. Atman, Identity, and Emanation: Arguments for a Hindu Environmental Ethic. Comparative Philosophy 2: 3-24. [CrossRef]

Framarin, Christopher. 2017. Hinduism and Environmental Ethics Law, Literature, and Philosophy. New York: Routledge.

Gottlieb, Roger S. 2003. This Sacred Earth, Religion, Nature, Environment. New York: Routledge.

Gottlieb, Roger S. 2010. Religion and the Environment. New York: Routledge.

Grapard, Allan G. 1982. Flying Mountains and Walkers of Emptiness: Toward a Definition of Sacred Space in Japanese Religions. History of Religions 21: 195-221. [CrossRef]

Jacobsen, Knut A. 2000. Bhagavadgita, Ecosophy T, and Deep Ecology. In Beneath the Surface: Critical Essays in the Philosophy of Deep Ecology. Edited by Eric Katz, Andrew Light and David Rothenberg. Cambridge: MIT Press, pp. 231-52.

Jnana, Das. 1994. Termeld meg önmagad! Sríla Prabhupáda programja a Krisna-tudatos önellátó Gazdálkodásról. Somogyvámos: Krisna-völgy. Kalantzopoulus, Nikos. n.d. Dystopian Realities, Utopian Ideals Auroville as the Foucauldian "Pirate Island" of the Twentieth Century. Available online: https:/ / www.academia.edu/36420431/Dystopian_Realities_Utopian_Ideals_Auroville_as_the_Foucauldian_ Pirate_Island_of_the_Twentieth_Century (accessed on 5 April 2021).

Kamarás, István. 1997. Devotees of Krishna in Hungary. In New Religions Phenomena in Central and Eastern Europe. Edited by Irena Borowik and Grzegorz Babiski. Kraków: Zaklad Wydawiczny Nomos, pp. 325-40.

Kamarás, István. 1998. Krisnások Magyarországon [Hare Krishnas in Hungary]. Budapest: Iskolakultúra. 
Klostermaier, Klaus K. 1991. Bhakti, Ahimsa and Ecology. Journal of Dharma 16: 246-54.

Koziol, Carol Ann. 2020. An Exploration of Four Ecovillages through the Ecoresilient Lens of Spirituality. Ph.D. Thesis, The Faculty of Graduate Studies Laurentian University, Sudbury, ON, Canada.

Lestár, Tamás, and Steffen Böhm. 2020. Ecospirituality and sustainability transitions: Agency towards degrowth. Religion, State and Society 48: 56-73. [CrossRef]

Lestár, Tamás. 2018. Disconnecting from technology on Hare Krishna farms. Human Geography 11: 43-56. [CrossRef]

Nelson, Lance E., ed. 1998. Purifying the Earthly Body of God: Religion and Ecology in Hindu India. Albany: SUNY Press.

Purusatraya, S. 1993. The Four Vaisnava Sampradayas. Vrindavana: VIHE.

Rigby, Andrew. 1974. Findhorn: Centre of Light. In Rigby, Andrew Communes in Britain. London: Routledge \& Kegan Paul, pp. 106-38.

Sanford, Whitney A. 2015. Almost Heaven, West Virginia: Food, Farming, and Utopian Dreams at New Vrindaban. Utopian Studies 26: 289-308. [CrossRef]

Smyer Yü, Dan. 2015. Sentience of the Earth: Eco-Buddhist Mandalizing of Dwelling Place in Amdo, Tibet. Journal for the Study of Religion, Nature and Culture 8: 483-501. [CrossRef]

Studley, John. 2019. Indigenous Sacred Natural Sites and Spiritual Governance: The Legal Case for Juristic Personhood. London: Routledge.

Tamm, Kadi. 2009. On Some Aspects of the Lilleoru Community. Journal of Ethnology and Folkloristics 3: 95-108.

Taylor, Bron, ed. 2010. Introducing Religion and Dark Green Religion. In Dark Green Religion: Nature Spirituality and the Planetary Future. Berkeley: University of California Press, pp. 1-12.

Vemsani, Lavanya. 2016. Krishna in History, Thought, and Culture. An Encyclopedia of the Hindu Lord of Many Names. Santa Barbara: ABC-CLIO, LLC. 